\title{
THE ROLE OF CAREER AND KNOWLEDGE MANAGEMENT IN RETENTION
}

\section{Dajnoki Krisztina $^{1}$, Szondi Réka ${ }^{2}$, Filep Roland ${ }^{3}$}

\author{
${ }^{1}$ Associate Professor, ${ }^{2,3} \mathrm{PhD}$ student \\ ${ }^{1}$ Department of Human Resource Management, Institute of Management and Organization \\ Sciences, Faculty of Economics and Business, University of Debrecen \\ ${ }^{2,3}$ Károly Ihrig Doctoral School in Business Economics and Organizational Studies, Faculty of \\ Economics and Business, University of Debrecen \\ E-mail: dajnoki.krisztina@econ.unideb.hu¹, szondi.reka@econ.unideb.hu², \\ filep.roland@econ.unideb.hu ${ }^{3}$
}

\begin{abstract}
Rapid response to changing environmental challenges plays a crucial role in maintaining competitiveness. For HR, achieving employee loyalty is one of the essential tasks that can solve the difficulties of the labour shortage. Retaining key workers is a growing problem today while attracting the right talented workforce to the organisation is critical. Employee satisfaction influences the level of loyalty, with the necessary recognition and appreciation of the individual's work, clear goals and expectations and the existence of a supportive organisational culture. Organisations' workforce retention capabilities are often linked to managerial attitudes, to the quality and systematic development of HR systems. The purpose of this study is to summarise and support, based on international literature and research, the importance of two key functions, career and knowledge management, for retention. As a result of the research, it is possible to determine the advantage of applying the two critical functions in retention management, and the difficulties and risk factors arising during the process can be defined. If the company does not focus on motivating its employees, it will significantly increase its costs as well as the time and energy invested in recruiting and selecting new employees. In conclusion, in addition to expanding the use of HR functions, successful loyalty increasing techniques include a career plan that supports both individual and organisational goals and an organisational culture that encourages knowledge sharing.
\end{abstract}

Keywords: career management; knowledge management; retaining; labour market; workforce JEL classification: $O 15$

LCC: HD58.7-58.95, HD5701-6000.9

\section{Introduction}

Over the past decade, organisation leadership has recognised that human resources play a crucial role in achieving sustainable competitive advantage and efficiency. In a world where knowledge and communication with customers are increasingly important, human capital, which represents the amount of knowledge, technical skills, creativity and experience of an organisation, is gaining more relevance and it is therefore seen as productive rather than a costly asset (Hendricks, 2002). The term "human capital" is considered to be a key element in improving the assets of the organisation as it provides a sustainable competitive advantage and increases employee efficiency. Some organisational theorists use the rules of human capital theory to prove that they can create this competitive position between companies through the development of human resources. Research shows that a standard indicator that is important at all levels of organisation management is human skills. Those working at the central levels of the organisation need to develop higher skills. These people must have got enough knowledge, information, innovation and creativity to increase customer satisfaction and create a 
competitive advantage for the organisation. Due to globalisation, the lack of workforce and talents generates progress in HR functions, meaning that they are becoming increasingly evident. The old and new functions used are closely related and have a significant impact on each other. The market advantage of retention-minded companies can largely depend on the emphasis on new features. An appropriate working environment and a supportive attitude of the organisation towards the advancement and development of employees is escalating.

The research question that induced necessity of the study was: Can a career and knowledge management system in the organisation contribute to employee loyalty? The research question examines the relationship between these functions. The aim is to gather corporate practices and techniques discussed in the literature to identify the most successful tools to retain.

The purpose of this study is to summarise and support, based on international literature in secondary research, the importance of two key functions, career and knowledge management, in retention. As a result of the research, it is possible to determine the advantage of applying the two critical functions in retention management, and the difficulties and risk factors arising during the process can be defined.

\section{Literature review}

\section{The significance of human capital and the expansion of HR functions}

Nowadays, companies face continuous challenges, which can be solved by a well-built HR system. The most noticeable problem in the labour market is the emerging labour shortage (Eurostat, 2018), which affects both small and large enterprises in Europe. The challenges induced by an ageing population are confronted by both developed and developing regions, and the decline in the employed population is causing a weakening in the supply system. As the value of human capital strengthens, companies will become more aware of various tasks related to managing human resources, such as recruitment, onboarding, training and development. If you do not develop and train your employees according to the current knowledge and information, the organisation will not be able to respond to the changes taking place around it. In their study, Wang et al. (2011) found a positive connection between human resource management practices and human capital.

Becker (1993) stresses special interest in on-the-job training as a possible form of investment in human capital. He distinguishes between general and specific training in his analysis. The difference is that, after completing a specific training, the individual enhances his productivity only within the company providing the training, but the competences acquired through general training can be utilised by other companies. In general training, the employee pays the full cost of the program, whereas, in the specific training, the costs are shared between the employee and the providing company. Blundell et al. (1999) claim that human capital can be divided into three main parts. The first is the initial, early ability of the individual, whether it be innate or acquired. Secondly, the knowledge and qualifications acquired in formal education. The third group contains the skills, competences and expertise that the individual acquires through on-the-job training. In parallel to its definition, the accumulation of human capital can be achieved through formal education, on-the-job training and learning from outside work. Human capital cannot be left out of the analysis of economic growth; its significance is indisputable.

The primary tasks of human resource management can be divided into two parts. Its first goal is to meet organisational goals, provide the right conditions for human resources and maximise their capacity. The second objective is to meet individual needs, to develop, encourage and 
maintain employees (Héder et al., 2018). The optimal principles of human resource management are (Berde - Dajnoki, 2007):

- human resources, the highest value of the organisation, the fundamental of successful operation rests on successful management,

- achieving business success is related to the relationship between human resources and company principles, mission and strategic goals,

- organisational culture, corporate values, atmosphere, and managerial behaviour all have an impact on employee performance, and it is the responsibility of management to ensure that organisational values are perceived and accepted by their employees.

The traditional activities of human resource management are continually evolving. While HR previously performed an administrative role, now it emerges as a strategic partner in corporate governance (Dajnoki - Héder, 2017). The role of HR is also evident in the development and business relations, as objectives include the continuous strengthening of its activities at the professional level and the harmonisation of its sub-functions. Traditional functions include workforce planning, job design, recruitment, selection, motivation, performance appraisal and development, but these days many new features have been added (Figure 1). The functions interact with each other, so the successful application of one function has a positive effect on the others.

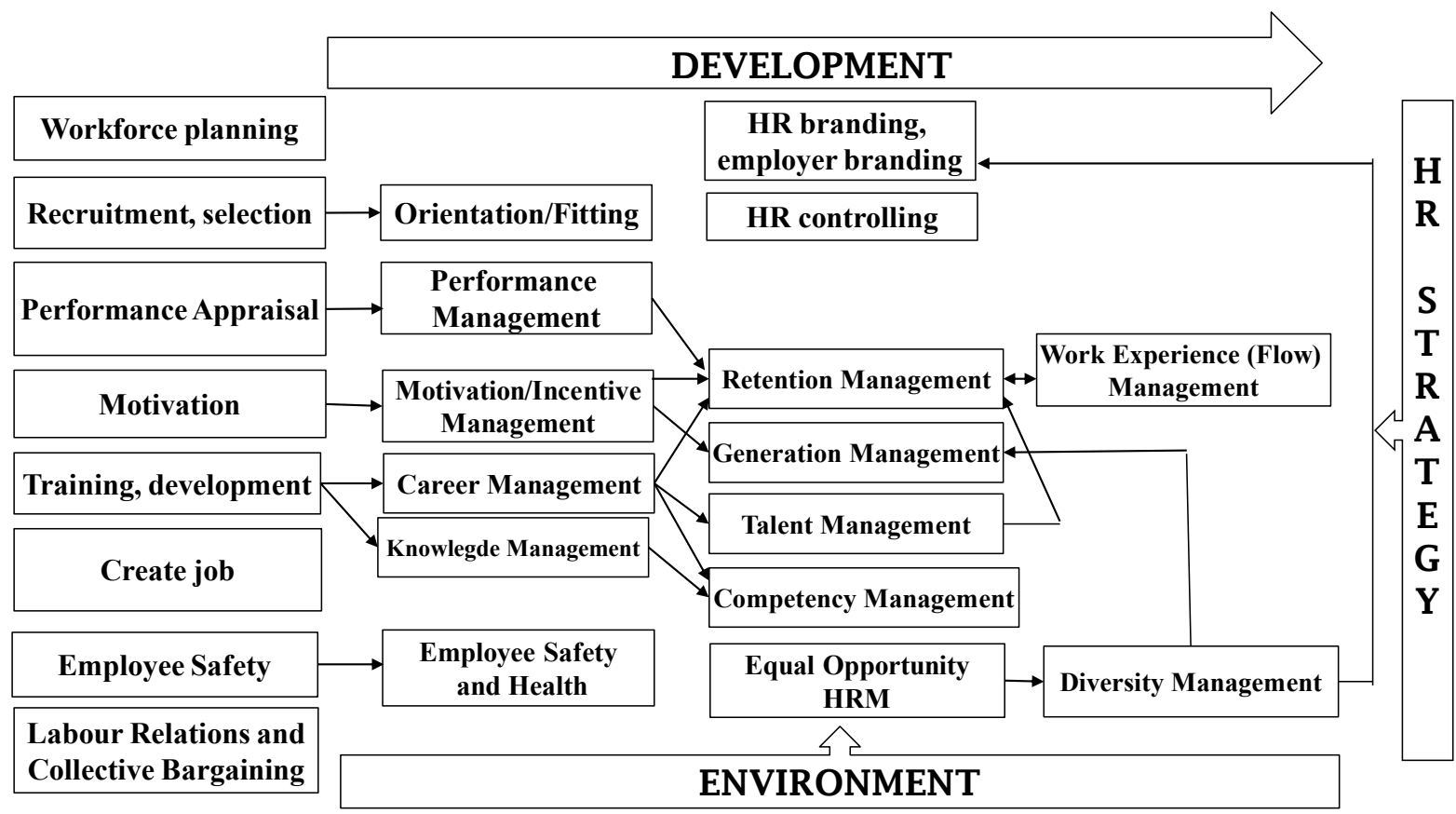

Figure 1.: The expanded HR functions

Source: Own editing on the basis of Dajnoki-Héder (2017)

The role of branding, recruitment, selection is considered necessary in finding talents, and the process can quickly fail if recruits and orientations are ignored. All functions in retaining the workforce become affected, besides the scope of incentives and cash benefits themselves, the proper working conditions, the availability of promotion opportunities and the need for development are also arising. The system should be integrated and the application of functions aligned with the strategy. Within Training and Development, there is also Career and Knowledge management. The study addresses Career, Knowledge and Retention management in more detail. 


\section{Advantages of a career management system, most commonly used tools}

Attracting talent to companies is essential to making the workplace attractive. HR professionals must convey corporate values and goals at all levels within the organisation and, once identified, connect with employees' individual goals and value systems (Erdei et al., 2017). Looking at the new graduate workforce leaving universities, we have to face the expectations of new generations. The $\mathrm{Y}, \mathrm{Z}$ and later generations pose a challenge to $\mathrm{HR}$, as they are motivated by different things and communicating through different channels; also their form of communication and their preferences deviates from others (Bencsik et al., 2017). Due to study periods being longer and the potential retraining (to make it easier to find employment in the labour market), Generation $\mathrm{Y}$ is just as active in the workforce with little experience as the younger Generation Z. Several factors can hinder the realisation of career planning and retention strategies. The relationship between the mentor and the participant facilitates knowledge transfer and exchange. Bilateral feedback is also correlated with satisfaction, costeffectiveness and loyalty (Bencsik et al., 2014; Csehné - Hajós, 2014, Čeryová et al. 2020). As the value of the workforce grows, companies face more and more challenges as the workforce number shrinks. Given the growing number of consumers and demand on one side, workers' expectations for their workplace have also increased in the other (Canton, 2013, Lajdová, 2016).

There are several approaches to interpreting career. Judge et al. (1995) stated that success equals positive or work-related outcomes that we obtain from our work experience. Arthur et al. (2005) reveal that success is a desirable highlight for work, while Judge - Kammeyer Mueller (2007) describes success as a result of work experience as a real or perceived result. Career definitions do not qualify when a career can be considered successful. Koncz (2013) expresses that certification is unnecessary; society gives feedback through different symbols; otherwise, the individual values his or her career. The problem arises if there is a conflict between the results of the two evaluations. Defining individual career success can change over time as you gain experience. Building an organisational career management system plays an important practical role in supporting employee success aspirations. A well-chosen career counselling method helps the employee to achieve their goals and successes (Szabó-Bálint, 2018). According to Baruch - Peiperl (2000), the most commonly used career management tools were:

- promoting internal job opportunities,

- formal training as a part of career development,

- benchmarking as a base for career planning,

- career consultation with the manager,

- a lateral movement to gather cross-functional experiences,

- career consultation with HR colleague,

- supply planning,

- formal mentoring,

- dual career paths (managerial and professional),

- written individual career plan.

Based on the research by Lewis - Arnold (2012) in trade organisations (UK), the most popular solutions have been the promotion of internal job opportunities, benchmarking, employee engagement, personal development plans and competence development. By interviewing the employee side, organisations have become more efficient, as the options set at the managerial level have not always been the same as those required by the employees. In her study, SzabóBálint (2018) discusses the 2014/16 yearly results of the Cranfield Network (an international human resource management research network coordinated by CRANET - Cranfield Business 
School), which analysed the response of 6481 organisations, of which $71 \%$ are European. The most common career management tools mentioned here are (Bálint - Karoliny, 2017):

- on-the-job training,

- participation in project teamwork,

- $\quad$ special work tasks,

- knowledge expansion project work,

- mentoring,

- coaching,

- succession plan,

- talent programs,

- formal career plans,

- planned job rotation.

The tools applied to underline the need for organisational engagement in the careers of employees, but an important factor is that individual perceptions of success may differ. As a result, the organisation can tailor and apply the capabilities of its toolbox, in consultation with the employee, to provide significant benefits. This helps to build employee loyalty and align individual and organisational goals.

\section{Benefits and disadvantages of implementing knowledge management}

There are many formulations known in the literature for defining the term. In one approach, data and information form the basis of knowledge. Data can be interpreted as a set of signs, while information can be interpreted as meaning attributed to data (Schreiber et al., 1998; Bögel, 1999). Information becomes knowledge when it generates a compulsion to act on its holder and processor. Knowledge is learned and used to enable an individual to act and influences the environment. According to Grant (1991, 1996) and Sveiby (2000), White (2003) classified the characteristics of knowledge into the following categories: substitutable (with other resources, time, money, work), transportable, shareable (its value does not decrease but increases), dynamic, appreciated by its use; its value is relative (depends on its environment), infinite and inexhaustible (not a scarce resource), difficult to represent or copy.

The new employee who comes to the company brings new knowledge and experience and a new way of thinking. In many cases, it is because of this unique ability that they hire or seduce a particular employee from a competing company. An organisation may even become dependent on the knowledge of an employee or employees by not sharing knowledge, the individual having only a knowledge monopoly. When an individual leaves the organisation, he or she takes away his or her fundamental knowledge and the mass of information he or she has acquired. Many companies define it as a problem when a highly skilled person leaves the organisation, a tremendous amount of knowledge is lost, and it becomes impossible to operate if they do not find a person with similar benefits.

The knowledge of an organisation is the sum of the knowledge of individuals (the amount of knowledge that members of the organisation shared and learned during their stay). It also includes intellectual property created by the employee but later used and owned by the company. A key factor here is the enhancement of employee loyalty and the utilisation of ideas within the organisation against the competing market players (America, 2000). On the one hand, the knowledge of the organisation is also growing, and the productivity of the individual's knowledge is gaining. 
On the other hand, the employee also receives knowledge from the organisation and other benefits for their work. Equality is achieved when both parties benefit equally from the process (Fehér, 2003). The time and cost factors involved in acquiring, creating, and expanding knowledge can thus become profitable later on (Table 1). White (2003) lists the cost of acquiring knowledge as they search for a person with the necessary knowledge, its attraction to the company and the personal and organisational costs related to the operation of the knowledge management system.

The phenomenon discussed in Table 1 does not always occur. Individuals tend to collect more information than they pass on. Training from the organisational side opens up a body of knowledge that the organisation has gathered from multiple sources and experience gained by multiple employees.

Table 1.: Investments and benefits in terms of knowledge

\begin{tabular}{|c|c|c|}
\hline & Individual side & Organisational side \\
\hline Investment & $\begin{array}{l}\text { Own knowledge, } \\
\text { experience } \\
\text { - Created intellectual } \\
\text { product, work }\end{array}$ & $\begin{array}{l}\text { - Costs of acquiring } \\
\text { knowledge } \\
\text { - Training expenses } \\
\text { - Payment } \\
\text { - Value of transferred } \\
\text { knowledge } \\
\end{array}$ \\
\hline Benefits & $\begin{array}{l}\text { - Organisational } \\
\text { knowledge and } \\
\text { experience } \\
\text { - Allowances }\end{array}$ & 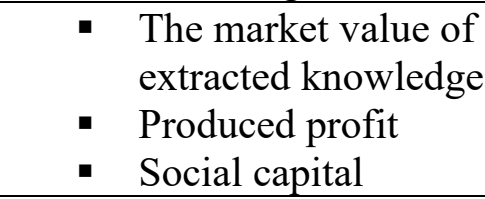 \\
\hline
\end{tabular}

Source: Own editing on the basis of Fehér (2003)

One of the most important goals of knowledge management is to improve organisational performance by promoting the practical application of knowledge (Veresné, 2013), which is a CRM (Customer Relationship Management) or SFA (Sales Force Automation System) management of customer capital) and can be implemented through human resources. In their research on knowledge-based companies, Bencsik and Juhász (2018) explained that knowledge management appears at a strategic level. Companies are open to preserving and enriching knowledge, which illustrates the growing importance of the area.

The most challenging factors that arise with this management field (both individually and organizationally) are: sharing the person's knowledge, overcoming resistance to knowledge management processes, and the problem of knowledge acceptance. It is a fundamental problem for knowledge sharing if the information accumulated is not displayed at the organisational level. There are several ways to gain employee knowledge, but none can be useful without maintaining motivation. Considering Skinner's (1969) reinforcement theory, our behaviour depends on environmental impacts (operant conditioning). To apply it, you need to know the organisational expectations for performance and the implications for them. Positive reinforcement, if the consequence is also positive, we reward and expect repetition. When individual shares their knowledge, they expand their knowledge base, receive rewards, receive various benefits, publicly reward, promote, or have individualised services and privileges. Confirmation is negative if there are no positive consequences. In some cases, not sharing or withholding may have more severe consequences, even dismissal (Pirc, 2000). Knowledge sharing is supported by a variety of collaborative software that enables the individual to visualise the knowledge immediately available to any member of the organisation. 
Understanding organisational memory can help managers identify and solve problems related to maintaining and utilising organisational knowledge. Such knowledge can lead to higher levels of organisational efficiency (Csapai - Berke, 2015), which can also result in gaining a competitive edge and determine the ability to innovate.

A successful career management system builds on competencies and development, thereby exposing the employee to the caring attitude of the organisation. Based on the feedback and career plans, the employee feels important and becomes more loyal in the long run. Individual and organisational goals need to be aligned, accessible, challenging, with appropriate managerial support in the background. With an optimised career management system, the company is prepared to replace potential key employees, makes human resource management tasks streamlined and efficient, and facilitates short, medium, and long-term development plans. In any case, the best tool is one that is close to the employee's vision and can be found in the organisation's directory.

A knowledge management system has many benefits, but for successful implementation, it is essential to know the dangers that may hinder its operation. Such hindering factors may include (Husted - Michailova, 2002; Gulyás, 2007):

- protecting one's competitive advantage, maximising one's performance,

- fear of "knowledge parasites" who absorb knowledge but do not share theirs,

- lack of time and supportive organisational culture,

- low level of motivation within knowledge sharing,

- lack of mutual trust,

- low or no managerial support,

- lack of financial resources and technology.

Recognition from leadership in the area of knowledge sharing and the creation of a supportive atmosphere help build and maintain trust between staff and organisational hierarchy levels. According to Brix (2017), organisational knowledge has an impact on individuals and team members in the process of creating it. Among the findings of Inkinen's (2016) study, he strengthens the modern vision required for knowledge sharing by management, which builds on the recognition of employees' knowledge and intellectual abilities. In the study of Gergely - Pierog (2018), besides knowledge, diligence, aptitude and support of the staff appear as influencing factors for the advancement within the organisation. The modern leader pays attention to creating a knowledge-friendly and trust-based organisational culture, anticipating the formation of the knowledge base in accordance with organisational goals.

\section{Implications for practice}

Regular feedback on performance and the involvement of the employee in decisions affecting him or her, foster the commitment to the company (Poór et al., 2012; Csedö et al., 2016). There are many benefits to using knowledge management systems. With a central knowledge base, accessibility and retrieval of previous data are also provided. It encourages teamwork and collaboration among employees and collects previously collected best practice collections. This is how individual implicit knowledge becomes explicit, accessible. For many years finding and attracting talents (talent acquisition) was the way to be successful, effective and innovative in the long run. Nowadays, talent hunting and trying to entice highly qualified labour is the aim, besides retaining. From another perspective, if a company put effort into their employees' development, they could create their talents which means they are building talents. This procedure will lead to the phenomenon that today's talents will be the average or regular 
employees in a few years (Z. Karvalics, 2017). Armstrong (2019) mentioned some factors that should be considered if a company would like to decrease its turnover rate. These factors include career moves (better prospects), more opportunity to develop skills, strengthening the relationship with the manager/team leader. Exit interviews are made to establish the reasons why people are leaving, not to convince them to stay. They could help find ways to improve management.

Confirming the previously gathered tools and practices in knowledge and career management, many pieces of research focusing on the mentioned factors. In a recent study based on firms from different countries, the findings show the following:

- In Chinese firms (96 firms): they should have embraced knowledge-based performance appraisals and strategic knowledge management practices more. These employee performance reviews have to be consistent and aligned with strategic knowledge focus in order to retain their employees and also their knowledge.

- In Russian firms (87): the firms' intellectual potential could be growing by investing in employee training and developments in the long run.

- In Spanish firms (180): knowledge-based compensation practices could bring many benefits. They do not typically reward the employees for sharing, creating and applying knowledge, but that has to be changed in the long run. If there is motivation, it could bring innovations and better performance as well (Hussinki et al., 2017).

This era is based on knowledge; both hiring and keeping talents is essential. Maintaining quality workforce culminates with some of the knowledge management factors as the organisational climate and values influence the employee's decision to stay for many years. The left includes the loss of knowledge and practical skills. Lazzarotti and others (2015) find that human resource management practices should be managed cautiously, for example, recruitment, selection, training, development, career, and reward systems in order to encourage knowledge transfer and innovative ideas. In Papa et al. (2018) research (based on 129 Italian firms, mostly in service industries such as IT software, food and beverage, textile and automotive) the findings supported the positive and significant connection between employee retention, knowledge acquisition and innovation performance. The authors pointed out that employee retention improves the effect of knowledge management and innovation, explaining that the retaining increases commitment and also trust among employees, thus helping knowledge specialisation. The results contributed to the idea of knowledge being the most critical resource for a company.

All in all, to retain key employees, the management and HR have to work together, they should agree in the aims and the strategy. For the labour, support from the management and feedback is important in order to develop and be committed. Knowledge and career management play an important role in future success by maintaining the essential knowledge, information, ideas, processes and also talents. Retention plans are designed to ensure that employees remain committed members of the organisation.

\section{Conclusions}

One of the most pressing issues in the labour market is getting the right workers to the right place. Attracting prospective employees to companies is not a simple task. Once a business reaches a specific size, it will require the use of HR professionals. Formerly an HR professional used to do administrative tasks, now a strategic partner for management, seizing opportunities and tools to achieve competitiveness. 
From the aspect of retaining employees, there is a need for complete consistency between HR functions. The two areas highlighted by the study are Career and Knowledge Management within the Development and Training function. Adaptation to continuous economic, environmental and technological changes is facilitated by a well-trained, up-to-date, motivated employee. If the organisation is planning for the long term with its workforce, the availability of the promotion system is vital. By enhancing the employee side, leadership support is the first step in commitment to development and motivation. Appreciation of corporate culture, values, and workforce is the foundation of a good employer brand. "A company is worth as much as the people it employs," the saying holds, confirming the importance of knowledge flow within the organisation and retaining key people. Retention is vital to ensure that employees feel they are valued. This study could be one of the first steps to new research, including the mentioned functions and their benefits in the long run.

\section{Acknowledgment}

This work was supported by EFOP3.6.3-VEKOP-16-2017-00007 - "Young researchers for talent" - Supporting careers in research activities in higher education program.

\section{References}

1. America (2000): America's Talent Battle - The Real Meaning of Empowerment, in The Economist, March 25, New York, pp. 87-89.

2. Armstrong, M. (2019): A Handbook of Human Resource Management Practice. 10th Edition. Kogan Page. London. 957 p.

3. Arthur, M. B. - Khapova, S. N. - Wilderom, C.P.M. (2005): Career success in a boundaryless world. Journal of Organizational Behavior, 26(2). pp. 177-202. https://doi.org/10.1002/job.290

4. Bálint B. - Karoliny Zs. (2017): The more is applied, the better results are reached? Empirical lessons learned from the usage of career management tools. International Journal of Strategic Management and Decision Support Systems in Strategic Management. Vol. 22, No. 4, pp. 3-10.

5. Becker, G. S. (1993): Human Capital. A Theoretical and Empirical Analysis with Special Reference to Education. The University of Chicago Press, Third edition.

6. Bencsik A. - Horváth-Csikós G. - Juhász T. (2017): Az Y és a Z generációval szembeni elöítéletel a munkahelyen. A munkahelyi elköteleződés felmérése és fejlesztési célok meghatározása. Taylor Gazdálkodás- és szervezéstudományi folyóirat. A Virtuális Intézet Közép-Európa Kutatására Közleményei. IX.évf. 2. sz. No. 28. pp. 121-128.

7. Bencsik A. - Juhász T. (2018): Tudásorientált szervezetek értékítélete a bizalom gazdasági hatásairól. In: Budapest Management Review. Vezetéstudomány. Vol. XLIX. No. 1. pp. 30-39.

8. Bencsik A. - Juhász T. - Machova R. (2014): Mentoring Practice on behalf of knowledge sharing in the light of education. Acta Polytechnica Hungarica. 11 (9) pp. 95-114.

9. Berde Cs. - Dajnoki K. (2007): A humánerőforrás gazdálkodás jelentősége és tevékenység területei, In: K. Dajnoki - Cs. Berde (ed.): Humánerőforrás gazdálkodás és vezetés, Szaktudás Kiadó Ház Rt., Budapest, pp.7-16.

10. Blundell R. - Dearden L. - Goodman A. - Sianesi B. (1999): Human Capital Investment: The Returns form Education and Training to the individual, the Firm and the Economy. Fiscal Studies, Vol. 20 No. 1. pp. 1-23. https://doi.org/10.1111/j.14755890.1999.tb00001.x 
11. Bőgel Gy. (1999): Tudásmenedzsment - a láthatatlan hatalom, megjelent: Magyar Távközlés, 1999. szeptember.

12. Brix, J. (2017). Exploring knowledge creation processes as a source of organisational learning: A longitudinal case study of a public innovation project. Scandinavian Journal of Management, 33 (2), pp. 113-127. https://doi.org/10.1016/j.scaman.2017.05.001

13. Canton, J. (2013). Global Futures Forecast 2013: The Top Trends That Will Shape the Coming Year. Institute for Global Futures.

14. Csapai Gy. - Berke Sz. (2015): Emotional factors influencing managerial growth, In: Csata, A - Fejér-Királ, G. - György, O. - Kassay, J. - Nagy, B. - Tánczos, L.J. (eds.) 12th Annual International Conference on Economics and Business, Editura Risoprint.

15. Čeryová, D. -- Bullová, T. -- Turčeková, N. -- Aamičková, I. -- Moravčíková, D. -Bielik, P. (2020): Assessment of the Renewable Energy Sector Performance Using Selected Indicators in European Union Countries. In Resources. 9, 102 (2020), s. 2020. ISSN 2079-9276.

16. Čeryová, D. -- Bullová T. -- Adamičková, I. -- Turčeková, N. -- Bielik, P. (2020): Potential of investments into renewable energy sources. In: Problems and Perspectives in Management. 18, 2 (2020), s. 57--63. ISSN 1727-7051.

17. Csedő Cs. - Frajna Piller A. - Horváth A. - Kolbe T. - Kovács T. - Poór J. (2016): Szakemberhiány és munkaerőmegtartás a kulcsmunkakörökben 2016. Kutatási zárójelentés, Budapest, 25.p. ISBN: 978-963-269-591-4

18. Csehné Papp I. - Hajós L. (2014): Education and working life in Hungary. Acta Technica Corviniensis - Bulletin of Engineering.2. pp..105-110.

19. Dajnoki K. - Héder M. (2017): „Új szelek fújnak” - a HR válasza a globalizáció és a változás kihívásaira. Hadtudomány: A Magyar Hadtudományi Társaság folyóirata 27: (E-szám) 2017, pp. 84-93. DOI 10.17047/HADTUD.2017.27.E.84

20. Erdei P. - Fenyves V. - Dajnoki K. (2017): A munkahelyi elköteleződés felmérése és fejlesztési célok meghatározása. Taylor Gazdálkodás- és szervezéstudományi folyóirat. A Virtuális Intézet Közép-Európa Kutatására Közleményei. IX.évf. 2. sz. No. 28. pp. 107-113.

21. Eurostat (2018). Europe employment statistics. https://ec.europa.eu/eurostat/statisticsexplained/index.php?title=Employment_statistics 2019.10.01.

22. Fehér P. (2003) Tudásmenedzsment: Problémák és veszélyek. Vezetéstudomány, Vol. 33. No. 4. pp. 36-45.

23. Gergely É. - Pierog A. (2018): A tehetség megtartásának lehetőségei a karrierigények tükrében. International Journal of Engineering and Management Sciences / Müszaki és Menedzsment Tudományi Közlemények Vol. 3. : No. 3. pp. 31-43.

24. Grant, R. M. (1991): The Resource-Based Theory of Competitive Advantage: Implications for Strategy Formulation, In: California Management Review, Spring, pp. 114-135. https://doi.org/10.2307/41166664

25. Grant, R. M. (1996): Toward a Knowledge-Based Theory of the Firm, in: Strategic Management Journal, Winter Special Issue, Vol. 12., pp. 109-121. https://doi.org/10.1002/smj.4250171110

26. Gulyás J. (2007): Tudásmenedzsment a magyarországi bankokban. Vezetéstudomány. XXXVIII. évf. 10. szám. pp. 45-54.

27. Hendricks, L. (2002). How important is human capital for development? Evidence from immigrant earnings. American Economic Review, 92 (1). pp. 198-219. DOI: $10.1257 / 000282802760015676$ 
28. Héder M. - Szabó Sz. - Dajnoki K. (2018): Effect of Labour Market Changes on HR Functions. Anali Ekonomski Fakulteta U Subotici / The Annals Of The Faculty Of Economics Subotica Vol. 54.: 39/2018 pp. 123-138.

29. Hussinki, H. - Kianto, A. - Vanhala, M. - Ritala, P. (2017): Assessing the universality of knowledge management practices. Journal of Knowledge Management, Vol. 21 No. 6, pp. 1596-1621. https://doi.org/10.1108/JKM-09-2016-0394

30. Husted, K. - Michailova, S. (2002): Diagnosing and fighting knowledge-sharing hostility. Organisational Dynamics 31: (1). pp.60-73. DOI: 10.1016/S00902616(02)00072-4

31. Inkinen, H. (2016): Review of empirical research on knowledge management practices and firm performance. Journal of Knowledge Management, 20 (2), pp. 230-257. https://doi.org/10.1108/JKM-09-2015-0336

32. Judge, T. A. - Cable, DM - Boudreau, J. W. - Bretz, R. D. (1995): An empirical investigation of the predictors of executive career success. Personnel Psychology, Vol. 48, p. 485-519. https://doi.org/10.1111/j.1744-6570.1995.tb01767.x

33. Judge, T. A. - Kammeyer-Mueller, J. D. (2007): Personality and career success. In: Gunz, H. - Peiperl, M. (eds.): Handbook of Career Studies. Sage Publications, Thousand Oaks, CA, p. 59-78. http://dx.doi.org/10.4135/9781412976107.n4

34. Koncz K. (2013): A sikeres szervezeti karrierfejlesztés feltételei. Munkaügyi Szemle, 57. évf., 4. sz., p. 32-43.

35. Lajdová, Z. -- Lajda, J. -- Kapusta, J. - Bielik, P. (2016): Consequences of maize cultivation intended for biogas production. In: Agricultural economics. 62, 12 (2016), s. 543--549.

36. Lazzarotti, V. - Manzini, R. - Pellegrini, L. (2015): Is your open-innovation successful? The mediating role of a firm's organisational and social context. The International Journal of Human Resource Management, Vol. 26, No. 19. pp. 24532485.

37. Papa, A. - Dezi, L. - Gregori, G.L. - Mueller, J. - Miglietta, N. (2018): Improving innovation performance through knowledge acquisition: the moderating role of employee retention and human resource management practices. Journal of Knowledge Management, Vol. 24 No. 3, pp. 589-605. https://doi.org/10.1108/JKM-09-2017-0391

38. Pirc, A. S. (2000): Organisational Learning and Knowledge Management. In: First European Conference on Knowledge Management, Remenyi, D. (ed), Management Centre International Limited, Reading, pp. 133-140.

39. Poór J. - Kolbe T. - Kovács I. É. - Sinka R. (2012): Megtartás - Fluktuáció; Magyarországi vállalatok és intézmények megtartási és fluktuációkezelési gyakorlata. Kutatási zárójelentés. Humán Szakemberek Országos Szövetsége, Budapest, 32.p.

40. Schreiber, A. Th. - Akkermans, J. M. - Anjewierden, A. A. - de Hoog, R. - Shadbolt, N. R. - Van de Velde, W., - Wieliga, B. J. (1998): Knwoledge Engineering and Management - The CommonKADS methodology, University of Amsterdam

41. Skinner, B. F. (1969): Contingencies of reinforcement: A theoretical analysis, Appleton Century Crofts, New York

42. Sveiby, K. E. (2000): What is Knowledge Management? in: http://www.sveiby.com.au

43. Szabó-Bálint B. (2018): A munkavállalói siker és az elérését támogató szervezeti karriermenedzsment-eszközök. Vezetéstudomány/Budapest Management Review. Vol. XLIX. No. 10. pp. 85-92.

44. Veresné Somosi M. (2013): Teljesítményalapú szervezetalakítás elmélete és módszertana. Miskolci Egyetem, Gazdaságtudományi Kar. ISBN: 978-963-358-0493 
45. Wang, M.-K. - Hwang, P. K. - Lin, S.-R. (2011): An empirical study of the relationships among employee's perceptions of HR practice, human capital, and department performance: A case of AT \& T Subordinate telecoms company in Taiwan. Expert Systems with Applications. Vol. 38. Issue 4. pp. 3777-3783. https://doi.org/10.1016/j.eswa.2010.09.038

46. Z. Karvalics L. (2017): A szervezeti információ- és tudásmenedzsment néhány új és újonnan azonosított szerepköréröl. Menedzsment innovációk az üzleti és a nonbusiness stférákban. SZTE Gazdaságtudományi Kar, Szeged. pp. 531-543. 